operation. It was very soft, and had as its nucleus many seeds of barley, which, with the beards, had been introduced by the urethra by the patient hinself, a silly foolish old man.

There are, noreover, several stones formed upon fragments which harl been broken down and left; specimens of that kind will, if I inistike not, nultiply exceedingly ere long. I expect to cut out not a few ; but I fear that many of them must be obtained by post-mortem exanination. I an warranted in stating that the stone-breaking has, upon the whole, been attended with far more numerous fatal terminations than ever lithotomy has been, even when performed in the worst possible manner, and by the most bungling pretenders. And such must be the case until the profession take it up and the proper cases are chosen; until its indiscri. minate employment is discountenanced; and if this be not done speedily, the operation, useful in many cases, will get ioto disrepute. The very simple and beautiful instruments manufactured by Messrs. Weiss will answer every purpose, and it will afford me great pleasure to explain to any of you their application, and to give you more fully my views and the result of my experience as to the proper cases for the one or the other operation.

['To be continued.]

HISTORY OF A FEVER IN SUNDERLAND, MASS. IN THE YEARS 1831-32.

BY GARDINER DORRANCF, M.D.

[Communicatod for the Boston Medical and surgical Jourual.]

Mr. Editor,-I have been requested to give you an account of a fever, which prevailed in Sunderland four years since, while I resided there. And I feel the more inclined to do it, as a better opportunity perhaps never offered to mark the progress of a typhous fever, which this very decidedly was, and deternine how far contagion comtributed to its spread.

The town, a small one of about 700 inhabitants, lying on the Connecticut River, had been proverbial for its health, until the winter of 1831, when scarlet fever and hooping cough, then prevalent in the region, sprend extensively through it. After their decline, some time in July, two boys, in the southern part of the town, were simulianeously atlacked with a lever, which sonn exlibited the marks of typhus; sucli as brown dry tongue, delirium, uwitching of the tendons, \&c.. A young man, who went from the village three miles north, to assist the family, contracted the fever of them, returned in the family to which he belonged, most of whom were soon attacked by it. He was then removed to another town, where his nother and sister apparently took from thim the same disease. The lamented minister of the place visited the two boys often, and sickened with fever. Nine of his family were soon prostrated with it. Himself and wife, after eight weeks sickness, with alternate favorable and unfavorable symptoms, worn down with anxiety for their sick children and friends, died within three days of each other.

From the fanilies named, the fever spread through nurses, watchers, and visitors, until sixty cases occurred. Or these sixty cases, six proved 
fatal. There was rothing in the fever at this time, very diverse from common typhus. It was not very inflammatory. 'The antiphlogistic regimen was required; but some recovered very readily without any loss of blood. When there was local determination, it wins generally to the hread. The usual length of the disease, when there was no relapse, was fourteen days.

The last case of fever occurred in Novernber, in a house adjoining my own. We then sipposed the disease at an end. About six weeks after, a little givl in the same house became unwell. I reasarked in her nother, that her tongue resembled the tongue in typhus, but that it could not be that, as typhous fever was extinct among us. Surb was not, however, the fact. A little daughter of mine, who frequently visited the sick girl, was soon attacked with fever. Thlis was followed by four other cases in my family. The little girl's mother and several oibers in the first house were soon sick. A young man nursing a firend in it, sickened and communicated the fever to his family. A boy, who succeeded him, did so to another fanily. Fever spread rapidly, uncil one hundred, principally in the village of fifty houses and perhaps three hundred inhabitants, were the subjects of it. Of these hundred cases, nine proved fatal.

'The fever at this time was severe in the extreme. In almost every case, there was strongly marked congestion, or inflammation of the brain. The lancet, used unsparingly at the onset of the disease, rendered it safe and mild. When neglecied at first, or used but timidly, almost every case ended in delirium, lethargy, and dropsy of head. Never before, nor since, have I seen the strong language of Southwond Smith respecting the timely alsstraction of blcood in fever attended with cerebral affection, so amply verified. And most bitter was my regret, when from excess of caution on my own part, or from neglect to yield to the disease on the part of the patient, the golden momem of disarming it of its power was allowed to pass. The nimety-one, whn rerovered, were most of them bled early and largely; the nine, who died, were not in general until days had gone by. The cold dash, recommended by the writer just inentioned, I tried in some cases after bleedling, with great satisfac.tion. I have seen a burning fever cooled, and raving delirium calmed, while pouring from a height the cold water, as he recommends, upon the head.

The general prevalence of fever abated in the spring. During the summer, there were a few cases. And there was between them, either a real or imaginary connection, continuing the chain until autumn, when the disease became common again, and forty cases of it occurred; but of a character very different from those of the presinus winter. Biliary derangement now took the place of congestion and inflammation of the brain. 'The season of the year probably caused this modification. Bleeding was now seldom indicated. Mercurials were the main reliance ; but, incautiously given, they prostrated the strength, sometimes to an alarming extent. In some parts of the valley of the Connecticut, the fever would now have been called "Iyphus symropalis." The mortality, during this last period, was less than in the two former nnes. The fever lasted in a few fatnilies, until winter, when it left the town, and has not returned. 
I know it is somewhat unfashionable in believe typhaus fever to be propagated by contagion. Some medical writers sit down gravely to discuss the point, whether munps and measles are connagious. In a great city, where the inmates of the same dwelling have ofien no intercourse; where the sick are attended hy hired watchers and nurses, whose vital air has become the atmosphere of a sick room, and where the very reprehensible practice of visiting the sick is not in vogue, it may not tee easily traced to contagion; and indeed typhous fever does unt ofien prevail extensively in a large city. But in a country village, where an intimary exists among all the farnilies, and where to not call upon the sick would show lack of friendship, a contagious disense can be traced, and typhous fever, I telieve, if introduced, is generally found to spread. Unlike bilious remitting, yellow and other fever's, caused by marsh miasm, or by infection, typhous fever seems to !lave a specific: power to communicate itself, in all climates, and at all seasons of the year. The first frosts do not check it, as they do yellow fever. In Sunderland, its greatest prevalence was in the dead of winter. Cleanliness, free ventilation, and, above all, secluding the patient, by keeping him in a chamber remote from his family, will do much to prevent the propagation of it. Still there is the specific power to communicate itself, to which we give the epithet contagious. And, after watching within the last ten years, in Sunderland and the neighboring towns, from three to four hundred cases of it, I can have no more doubt of its possessing that power than I have that smallpox does.

Dr. Tweedie, physician to the London Fever Hospital, certainly a conspetent witness in the case, says, "he has no besitation, after an inpartial inquiry into the subject, and ample means of investigation, in affirm his decided conviction that fever will spread by contaginn." And so, I believe, will say almost every physician who has been very much conversant with the kind of fever I have described above.

Amherst, July 16, 1835.

\section{A SUMMARY PROCESS FOR THE PREPARATION OF MERCURIAL OINTMENT.}

BT JOHN P. METTAUER, M.D. OF PRINCE EDWARD CO. VIRGINIA.

[Cominulicated for the Boston Medical and Surgicnl Journnl.]

THE importance and value of Mercurial Ointment as a medicinal agent, and the difficulty generally acknowledged in preparing it, will, I am persuaded, secure for the following communication at least an indulgent reception from the medical public.

The design of this paper is to present a short and easy method for preparing this valuable article, which will not only abridge the process, and cheapen the price, but furrish it fresh, and of known and certain strength, to every practitioner who will allow himself 25 or 30 minutes time to prepare it.

The division of the metal, by triturating it with terebinthinates, although it greatly facilitates the process, furnishes an ointment exceedingly objec- 